\title{
Anomalies between Orthography and Pronunciation in English and Suggestions to Mitigate the Problems
}

\author{
Dr. Arun Behera \\ Associate Professor, Dept of English Language \& Literature, \\ Sri Sathya Sai Institute of Higher Learning, Bangalore-560 067
}

\begin{abstract}
English is one of only a handful few non phonetic dialects where there are heaps of oddities among spellings and sounds. Obviously, one of the fundamental reasons is that English has 26 letters that can generate 44 sounds. Letters of the English are stringed together in a specific order to shape words which are portrayed with phonetic features. There is an absence of pattern as far as letters and sounds are concerned thus making the pronunciation erratic especially for L2 speakers. It is therefore necessary that these errors are identified correctly for the non-native speakers of English to avoid lapses. This investigation attempts to distinguish and analyse the explanations behind this issue and also to offer a few recommendations to mitigate the issues relating to spelling and sound.
\end{abstract}

Keywords - Phonetic; Sound; Spelling; Language; L2 Speaker; Pronunciation

\section{Introduction}

The innovation of the print machine brought about a huge change in the literary space. Whatever was being written physically, particularly in English, came to be accessible in print. However, it carried alongside it a decent amount of issues - its conflicting spellings turned out to be extremely glaring. It came as a shock to individuals who up to that point had not come across a case wherein the spellings didn't coordinate with the sounds the letters created.

Each of the 44 sounds of the English language is spoken by at least one or more than one letters or blend thereof. Additionally, every one of the 26 letters of the English alphabet likewise delivers at least one or more than one sounds. It may be noted here that some of these letters may not produce any sound at all, for example silent letters. This is fundamentally on the grounds that English needs textures regarding orthography and sound. Sharma (2003:43) says, "The spelling of most languages shows anomalies and inconsistencies, but that of English is, so far as its relation to the spoken word is concerned, quite crazy. In many languages the spelling of a word is a good guide to it's conversely, sound, and, the sound directs to the spelling. This is positively not true of English."

At the early stage of writing, for certain obscure reasons individuals didn't make a fuss over the principles of spelling and articulation. It was for the most part felt that as long as whatever an essayist said was understood, the spelling didn't make much difference. It implies that individuals focused on additional on the semantic piece of the language as opposed to the phonetics. Howard (1741:1078) wrote: "Letters are the first elements of speech, as being individual articulate voices or sounds. In English, the orthography is more vague and unascertained than in any other language. Each author, and almost each printer, has his meticulous system: nay, it is scarce so well with us as that: we not only diverge from one another; but there is scarce any that consists with himself. The same word shall recurrently appear with two or three dissimilar faces in the same page, not to say line."

There are, I accept, in any event three fundamental reasons, why there is no cognizance between the composed word and the verbally expressed word in English. The point Pink and Thomas (1974:5) raised has pertinence here for they accepted that the absence of consistencies was for the most part because of recorded reasons. "Before that time the scribes had observed no consistency in the content of spelling but when printing was made-up and books began to multiply, it was found essential to adhere to some definite system. Thus, the early printers produced a system of spelling which has persisted with few changes, ever since."

The primary explanation behind these abnormalities could be ascribed to the French recorders who in the fifteenth century had presented written symbols (from French) to represent English sounds. One of the more typical models is the utilization of letter ' $c$ ' which is articulated as/s/ in sun as in the words cinema, cite, cell, placing, racer, sorcery, nice, price, place and so forth instead of different sounds that the letter 'c' represents, for example $/ \mathrm{k}$ /as in card, focal, lac and so on.,/t $\mathrm{f} / \mathrm{as}$ in cello, concerto (the second ' $c$ '), ciao and so on., or/ $/ /$ as in social, precious, artificial, or even silent letters as in czar, victuals, scene and so on. So also, the letter ' $u$ ' in the mix of letters 'gu' as in words like guest, fatigue, plague and so on remain silent. Additionally, the combination of 'ou' or 
'ow' brings about the diphthong/av/ as in house, spouse, cloud, and crown, frown, now etc.

It may not be out of context here to quote Dhand (2018:v) who says, "Modern spelling was fixed in the fifteenth century, and represented the pronunciation of that century. The use of the letter ' $c$ ' for the sound /s/ as in words like city, cinema, mice, race etc., 'gu' for /g/ as in guest, guess, etc., 'qu' for O.E. 'kw' as in quick, queen, etc., and 'ou' or 'ow' for the diphthongal sound /av/ as in house, cow etc."

Furthermore, an endeavor was made to cause the spelling of words to hold their historical underpinnings or their source. The Norman-French words 'dette' and 'doute', for instance, held their spellings when they were first presented. Afterward, obviously, they were written 'debt' and 'doubt' respectively perhaps to show their association with Latin 'debitum' and 'dubitum'. Obviously the sound/b/has never been articulated; it stayed silent all through as in words like plumber, subtle, climb, thumb and so on. Dhand's (2018:v) observation may help us understand the sound-spelling inconsistencies when she says, 'The Norman-French words 'dette' and 'doute', for example, retained this spelling when they were first introduced. They were later written 'debt' and 'doubt' in order to illustrate their connection with Latin 'debitum' and 'dubitum'. The 'b' has never been pronounced."

The third explanation could be that the English pronunciation has experienced huge scale changes since the print machine came to being in the fifteenth century, for example since Caxton's time though the spelling framework remained generally flawless. At the end of the day, the sound framework continued changing while the spelling rules, to a significant degree, stayed consistent. To quote Dhand (2018:v), "However, when printing was invented and books began to multiply, it was found necessary to adhere to some definite system. When it is added that English pronunciation has undergone many and far-reaching changes since Caxton's time, one reason for the lack of correspondence between the written word and the spoken sound will become clear. The symbol 'gh', for instance, which is now silent in words like sought, fought, brought etc., and which, in words like laugh, rough, enough, etc., has the sound of /f/, originally represented one and the same sound in all these words. Again, the symbols 'ee' in bleed, need, speed etc. or 'ei' in ceiling, receive, conceit etc. in the 15th century represented a different sound from that of 'ea' in bead, leak, plead etc. though these three symbols represent the same sound."

\section{Mismatch between Spellings and Sounds}

i) The same sound(s) is/are not always produced by the same letter(s) or combination thereof. ii) Some letters, at times, become silent; in other words they are not pronounced at all

iii) The same letter(s) do(es) not always represent the same sound(s)

iv) The morphemes are pronounced differently when changed to plurals (-s/-es) /s, z, Iz /or past tense (-d/-ed) /d, Id, $\mathrm{t} /$

v) Some sounds are pronounced in some places even when there is/are no letter(s)

Let's examine these problems threadbare:

i) The equivalent sound(s) is/are not generally created by the equivalent letter(s) or mix thereof.

The phoneme / $t /$ is generated by digraphs, e.g. 'pt', 'th' or trigraphs, e.g. 'ght' as is shown below:

$\mathrm{t}$ as in time, voter, date

$\mathrm{tt}$ as in matter, cutter, shutter

pt as in receipt, ptarmigan (an animal found in the Arctic region), pterodactyl (an animal in the late Jurassic period)

bt as in doubt, debt, debtor

ct as in indict, victuals (food-archaic), Connecticut

th as in Thames, Thomas, Anthony

cht as in yacht, chthonic (relating to the underworld)

ght as in caught, sought, brought

Similarly, the sound $/ \mathrm{k} /$ is produced by the letters, 'c', 'q' or digraphs, e.g. 'cc', 'cq', 'ch', 'kh' etc. Some examples are given below to show the discrepancy.

$\mathrm{k}$ as in kite, maker, yak

kk as in trekking, abattoir, abutting

$\mathrm{kh}$ as in khaki, khadi, khalif

$\mathrm{c}$ as in camera, cone, coma

cc as in Mecca, occur, recce

ch as in mechanic, chemistry, alchemy

ck as ain lock, pick, pluck

$\mathrm{q}$ as in queen, queue, opaque

cq as in acquaint, acquit, acquire

Also, the letters or the digraphs, e.g. 'c', 'ti', 'tu', 'cz', or trigraphs, e.g. 'tch' etc. produce the sound $/ \mathrm{t} \mathrm{f} /$. Let's see the examples below to appreciate the mismatch between letters and sounds in English:

ch as in chart, chair, choose

tch as in match, catch, latch

c as in cello, ciao, concerto

tu as in mature, creature, feature

ti as in question, questionnaire, questing

ght as in righteous

$\mathrm{cz}$ as in Czech

One more sound $/ \mathrm{d}_{3} /$ is produced by a letter, e.g. 'j', 'd' or digraphs such as 'dg', 'gg' (list below):

$\mathrm{j}$ as in joke, jury, major

$\mathrm{jj}$ as in hajj, hajjes, hajji

$\mathrm{dg}$ as in pledge, judge, hedge

$\mathrm{g}$ as in gem, germ, courage 
gg as in suggest, exaggerate

$\mathrm{d}$ as in educate, gradual, graduate

The sound /f/ is also an interesting one which is produced by letters as varied as ' $\mathrm{f}$ ', ' $\mathrm{v}$ ', ' $\mathrm{w}$ ', or digraphs, e.g. 'pf', 'ft' etc. which can be clearly observed in the list here:

$\mathrm{f}$ as in fall, loafer, surf

ff as in suffer, cuff, bluff

ph as in phone, phonetics, morph

$\mathrm{v}$ as in Volkswagen, Chekhov

pf as in Pfeiffer

$\mathrm{ft}$ as in often, soften

If as in calf

w as in Krakow

The phoneme / $/$ / also is no exception. It is generated by letters such as ' $\mathrm{f}$ ' and digraph, e.g. 'ph' as can be seen here:

$\mathrm{v}$ as in van, cover, save

$\mathrm{vv}$ as in savvy

$f$ as in of

ph as in Stephen

The sound / $/$ / is one more case wherein it is produced by letters, e.g. 'c', 's', 'x' or digraphs, e.g. 'ch', 'ss', 'sc', or trigraph, e.g. 'sch', etc. The words below suffice the argument.

sh as in shirt, cushion, bush

ch as in machine, chef

$\mathrm{s}$ as in sure, pension, sugar

ss as in fissure, passion

$\mathrm{c}$ as in ocean, facial, racial

sch as in schedule, schmaltz

$\mathrm{sc}$ as in crescendo

$\mathrm{x}$ as in noxious [injurious to health]

ii) Some letters, on occasion, become silent; as such they are not pronounced by any means.

Given below are some words as examples:

B - Climb, debt, plumber, subtle, subpoena, thumb, bdellium

G - Align, alight, champagne, diaphragm, gnash, high, reign, though

P - Corps, coup, cupboard, pneumonia, psalm, raspberry, receipt, Pfeiffer, Ptolemaic

T - Chevrolet, depot, listen, mortgage, apostle, waltz, tzar, tsar, Renault

W - Whole, write, wrong, two, sword, wrist, answer, hawk, Z-Rendezvous, laissez-faire, tzetze, Czech

iii) The equivalent letter(s) do(es) not generally speak to the equivalent sound(s)

As we see, in the following examples, the letter does not always represent the same sound in English. Some letters can stand for as many as nine sounds. Let's look at the following examples:

The letter ' $a$ ' is realised as

$/ æ /$ as in axe, carry, map

/eI/ as in age, tape, slave

/a:/ as in arm, bath, car

/e/ as in many, anything, lemonade

/ə/ as in above, was, about

$/ \mathrm{I} /$ as in village, bondage, cabbage

/o:/ as in warm, water, war

/eə/ as in care, parent, spare

Similarly, the letter ' $c$ ' is realised as

$/ \mathrm{k} /$ as in call, cart, camera

/s/ as in cell, cinema, cite

$/ \mathrm{t} \mathrm{f} /$ as in cello, ciao (an exclamation), Cembalo (Italian)

$/ \mathrm{J} /$ as in social, facial, racial

The letter 'o' is realised as

$/ 0: /$ as in cord

$/ \partial v /$ as in robe

$/ \partial /$ as in control

$/ \Lambda /$ as in colour

/3:/ as in word

/u:/ as in move

/o/as in woman

$/ \mathrm{I} /$ as in women

$/ \mathrm{p} /$ as in opossum

The letter ' $\mathrm{s}$ ' is realised as

/s/ as in sun

/z/ as in Caesar

$/ 3 /$ as in pleasure

$/ \mathrm{d} z /$ as in Asia

$/ \int /$ as in sure

iv) The morphemes are articulated distinctively when changed to plurals (- s/ - es)/s, z, Iz/or past tense (- d/ ed)/d, Id, t/

Another area of problem for L2 speakers of English is the pronunciation of the plural and past tense morphemes. We know that plurals are formed by adding -s/-es to the root word. Similarly, past tense forms are obtained by adding $-\mathrm{d}$ /-ed to the root word. However, when these -s/-es or $-\mathrm{d} /$-ed are added to base words, the pronunciations change noticeably. For example, dogs is realised as /dngz/ or houses as /hauzIz/. And washed is realised as /wp/t/ or started as /sta:tıd/.

v) Some sounds are articulated in certain spots in any event, when there is/are no letter(s).

One of the several problems with regard to the spelling-sound mismatch in English is the intrusion of sound where there is no spelling to indicate that sound. In other words, certain sounds are pronounced even when

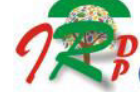


there is no letter to indicate the corresponding sound. Some of the examples are:

$/ \mathrm{k} /$ as in words like accident, axle, axis, access, accept, axe. In these words, $/ \mathrm{k} /$ is the extra sound which confuses the L2 speakers. $/ \mathrm{j} /$ as in cute is pronounced before $\mathrm{u}$ in some words giving an extra sound. For instance, in words like use, mute, Europe, eulogy, cube, fuse etc. the / $\mathrm{j} /$ sound comes before $\mathrm{u}$ thus making it difficult for non-native speakers. $/ \mathrm{w} /$ is inserted before the letter ' $\mathrm{o}$ ' in one, once etc. Non-native speakers are used to pronounce words with 'o' as /əo/ as in bone, stone, go, slow etc.

\section{Recommendations}

We recommend beneath certain measures to fix the issues identifying with spelling-sound in English. A language is actually how the speakers whose native language it is say; it isn't the manner by which it ought to be said. Thus, it is vital that pronunciation rules are taught from an early stage of training, for example in the formative years of a child. In the event that it is pushed to a later stage, the issues may stay lasting and hard to deal with. The facts confirm that there are no similarities between the spellings and sounds of numerous English words, yet it is additionally a reality that there are some discernible patterns.

It is important for us to advise the speakers of the principles that oversee the pluralisation and the past tense. It is a fact that there are special cases to rules, but to a huge degree the guidelines will assist speakers with learning the right pronunciation at least with regard to specific sounds.

\section{Rules with Plurals}

If there should be an occurrence of plural arrangement, - s/ - es is added to the base word. The addition of - $\mathrm{s}$ makes/s/sound if the thing closes in a voiceless or unvoiced consonant sound as in: maps, cats, books, surfs, myths and so on. Be that as it may, the sound becomes/z/if the thing closes in voiced consonant sound as in: mobs, buds, rags, moves, writhes, names, buns, kings, cells, cars and so forth. The equivalent is the situation with vowel sounds since all vowels are voiced, for example seas, cities, shoes, errs, jaws, days, flies, boys, shows, fears, fairs and so forth. At whatever point the base thing closes with/s, $\mathrm{z}, \int, \mathrm{t} \int \mathrm{d} / \mathrm{d} /$ the sound delivered is/Iz/as in buses, mazes, trashes, churches, judges and so forth. As it were, if the thing closes with a sound other than the five unvoiced consonants (/s, $\mathrm{z}, \int, \mathrm{t}$, dz/), articulate 's' with a/z/or with an /Iz/ by and large.

\section{Rules with Past Tense}

So also, - d/ - ed is added to frame the past tense which is acknowledged as/d, t, Id/. It produces/d/sound if the action word base finishes in voiced sounds aside from/d/(/b, g, d3, v, ð, z, 3, m, n, y, l/) as in robbed, bagged, judged, moved, writhed, prized, rouged, claimed, banned, wronged, pulled respectively.

A similar principle applies to words finishing with vowel sounds as well, for all vowels are voiced. A portion of the regular models are: guaranteed, shoed, erred, flawed, played, dried, flowed, feared, fared, cured and so forth. The/t/is mixed together with the past consonant and not articulated as an additional syllable. In any case, it results $\mathrm{in} / \mathrm{t} /$ if the verb base ends in voiceless sounds (/p, k, f, $\theta, \mathrm{s}, \int$ $\mathrm{g} /$ ) as in snapped, plucked, coughed, mouthed, missed, smashed, hatched respectively. The/d/is mixed together with the previous consonant and not articulated as an additional syllable. Be that as it may, it becomes/rd/ if the base ends in/t/or/d/as in painted, decided etc. In these cases, however, the/t/or the/d/is articulated as an additional syllable.

\section{Conclusion}

It is absurd to expect to take out every one of the issues relating to an unknown dialect. It is, nonetheless, plausible to improve the way the L2 speakers pronounce, particularly with respect to basic blunders that make their English unimaginable. We should, along these lines, cause them to comprehend the genuine issues, for example, the irregularities among sounds and spellings and furthermore give them enough to rehearse. Prescribing the L2 speakers to utilize a decent lexicon will go a long way in revising their English pronunciation.

\section{References}

[1] Behera, Arun. (2012). Speaking English Fluently. New Delhi: Sanbun Publishers.

[2] Behera, Arun. (2011). The World of Portmanteau Words. Chennai: Vijay Nicole Imprints Pvt Ltd.

[3] Dhand, Deepika. (2018) Simplifying Spelling Structures. Mumbai: Himalaya Publishing House. Pp.v.

[4] Howard, George Selby. (1741) The New Royal Cyclopaedia and Encyclopaedia. London: Alex Hogg. Pp 1078.

[5] Jones, Daniel. 16 $6^{\text {th }}$ ed. (2003). Cambridge English Pronouncing Dictionary. Noida: Cambridge University Press.

[6] Okeke, Nneka Umera. Spelling and Phonetic Inconsistencies in English: A Problem for Learners of English as a Foreign/Second Language. African Research Review Vol. 2 (1), Jan 2008. Pp 65-66.

[7] Pink, Alderton M. \& S. E. Thomas. (1994) English Grammar, Composition and Correspondence (12th ed.). Reading: Donnington Press.

[8] Sharma, Tara Chand. (2003) Modern Methods of Teaching English. New Delhi: Sarup \& Sons. Pp43. 